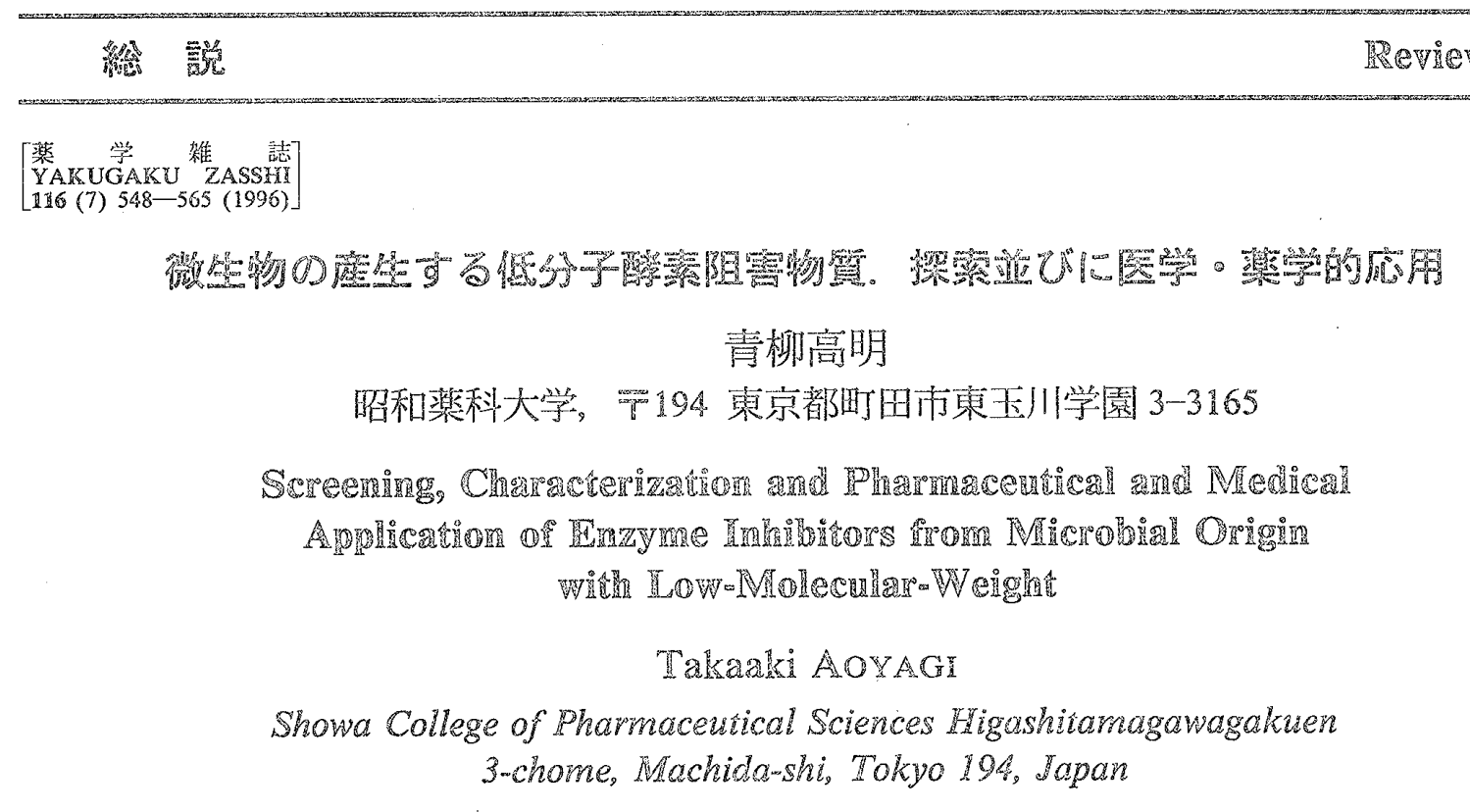

(Received April 1, 1996)

In living organisms a large number of enzymes are working in complicated networks to express various biological functions. In order to analyze such functions from various aspects, specific enzyme inhibitors are likely to become useful tools. They are also useful for the studies of reaction mechanisms and analysis of three-dimensional structures of enzymes. Moreover, they are of great value in elucidating disease processes and seem to have usefulness in treatment of various diseases.

Searching for inhibitors in culture filtrate of microbes, we discovered many substances which specifically inhibit various enzymes such as endopeptidases, exopeptidases, glycosidases, lipases, an so forth. These inhibitors have lowmolecular-weights and unique structures. We found significant activities of exopeptidases, alkaline phosphatases, esterases, and so forth, on surface membranes of various mammalian cells. Searching for specific inhibitors against these cell surface enzymes, we have discovered many interesting inhibitors. These inhibitors proved to bind to the cellular surface and to modify the functions of cells involved in immune responses.

Thus the studies on these enzyme inhibitors may well afford important keys to understand various aspect of biological phenomena and diseases: inflammation, immune response, hypertension, hyperlipemia, diabetes, Alzheimer's disease, carcinogenesis, metastasis, viral infection, autoimmune diseases, and so forth. Because of their interesting pharmacological activities, some of the inhibitors are now under clinical evaluation for their uses as medical drugs. Enzyme inhibitors seems to propose a new promising field of science.

Key words enzyme inhibitor; protease inhibitor; glycosidase inhibitor; Alzheimer's disease; autoimmune disease; hypertension

䤃素並びにその阻害物質は，個体発生から老化に至るすべての生命現象と湂いつながりを有 している。生体のHomeosiasis（恒常性）を乱す様々な現良を理解するには，生体内における酵

本総説は，平成 8 年度日本薬学会学術貢献賞の受賞嶪績を中心に記述したものである。 
素並びに阻害物質の役割を理解することが大切である. 生体内で作用する各種の酵素は，個々 の独立した反応として作用するより，相互に因果関係を持った連鎖反応，すなわちネットワー クとして作用している。疾病は，しばしば動的平衡の乱れを原因として誘起されるが，逆に疾 病によって動的平衡の乱れが引き起こされることあ当然考えられる.

生体の Homeostasis を究明するため, 正常及び病態動物の血清, 臓器内の各種の酵素活性の 変動を経時的に調へ，また酵素阻害物質を長期間投与することにより誘起される酵素網の変動 を究明した。阻害物質の生体内における動態を明らかにするととすに, 難病を含む様々な疾病 に新しいアプローチを試みることができるようになった。 かくして，病態解析を行うことによ り key enzyme を選出し, この標的酵素に対する阻害物質を探索する. 新規阻害物質を発見しえ たなら，これをリード化合物として類縁化合物を合成し，その治療効果を調べるという strategy の基に，常に新しい領域の開拓を目的としている。

標的酵素に対する阻害物質の探索研究は, 故梅沢浜夫先生創始の微生物化学研究所において 施行し, 微生物二次代謝産物から 60 以上の新規構造を有する低分子酵素阻害物質を発見し た。 ${ }^{1-10)}$ 同研究所における酵素阻害物質の研究が飛躍的発展を遂げたばかりでなく，この領域 の今日の隆盛が築かれたのである。微生物代謝産物から, 人類の福祉に貢献し得る医薬などを あっと開発すれば，地球上の限られた資源と異なり，無限の富をもたらしてくれるすのと信じ る。

本稿では，微生物代謝産物として発見した多数の新規構造を有する低分子酵素阻害物質を中 心に，最近の知見を述べる。

\section{I. 生化学的方法論への寄与}

1. 酵素阻害物質の醅素学への寄与 a) 酵素の精製—Leupeptin, Antipain, Poststatin, Pepstatin, Phosphoramidon, Amastatin, Bestatin, Benastatin などのアフィニティクロマトグラ フィーは酵素の精製を容易にするとともに，新しい䤉素発見の糸口になった。ことに Pepstatin アフィニティクロマトグラフィーはレニン, プロレニンなどの精製を可能にし, 血圧調節に関 与するレニン・アンジオテンシン系の作用機序の解明に貢献している. また Pepstatin, Phosphoramidon などの酵素複合体は差スペクトルによる酵素の純度の測定を可能にした。さらに, ペプチド様阻害物質 (Pepstatin, Leupeptinなど) はマルチエンザイムシステムにより $\mathbf{N}$ 末端か らC末端へと段階的に生合成されることを明らかにした。

b) 立体構造の解明——立体構造の解析が困難であった酵素は阻害物質との複合体を作るこ とにより X 線解析による立体構造の解析を可能にした。すなわち，ペプシンと Pepstatin，サー モライシンと Phosphoramidon などは複合体のX線解析により立体構造が明らかにされた。こ れらの研究はコンピューターグラフィックによる酵素の活性部位の解明，また新しい阻害物質 を合成する屝を開き，構造・活性相関の研究の飛躍的発展をむたらした。

2. 酵素阻害物質からみた酵素学 プロテアーゼは合成基質に対する作用様式並びに触媒 残基に基づき, Fig. 1 のように分類されている.一方, 多数の特異的阻害物質が発見され集大成 された結果，阻害物質によるプロテアーゼの分類が不可欠になった (Fig. 1). また酵素-阻害物 質複合体は酵素のX 線解析を容易にし, 多くの酵素の解析を促進した。さらにコンピューター グラフィックを用いた新しい阻害物質の合成への道を拓いたことは, 多くの疾病に対する新し い治療薬の開発研究に大きな貢献を与えている.

プロテアーゼ，グリコシダーゼを含む多くの酵素において，阻害物質の特異性から分子種の 存在が明らかにされた．酵素分子の進化を考えるうえに重要な発見である．さらに，エクトエ 


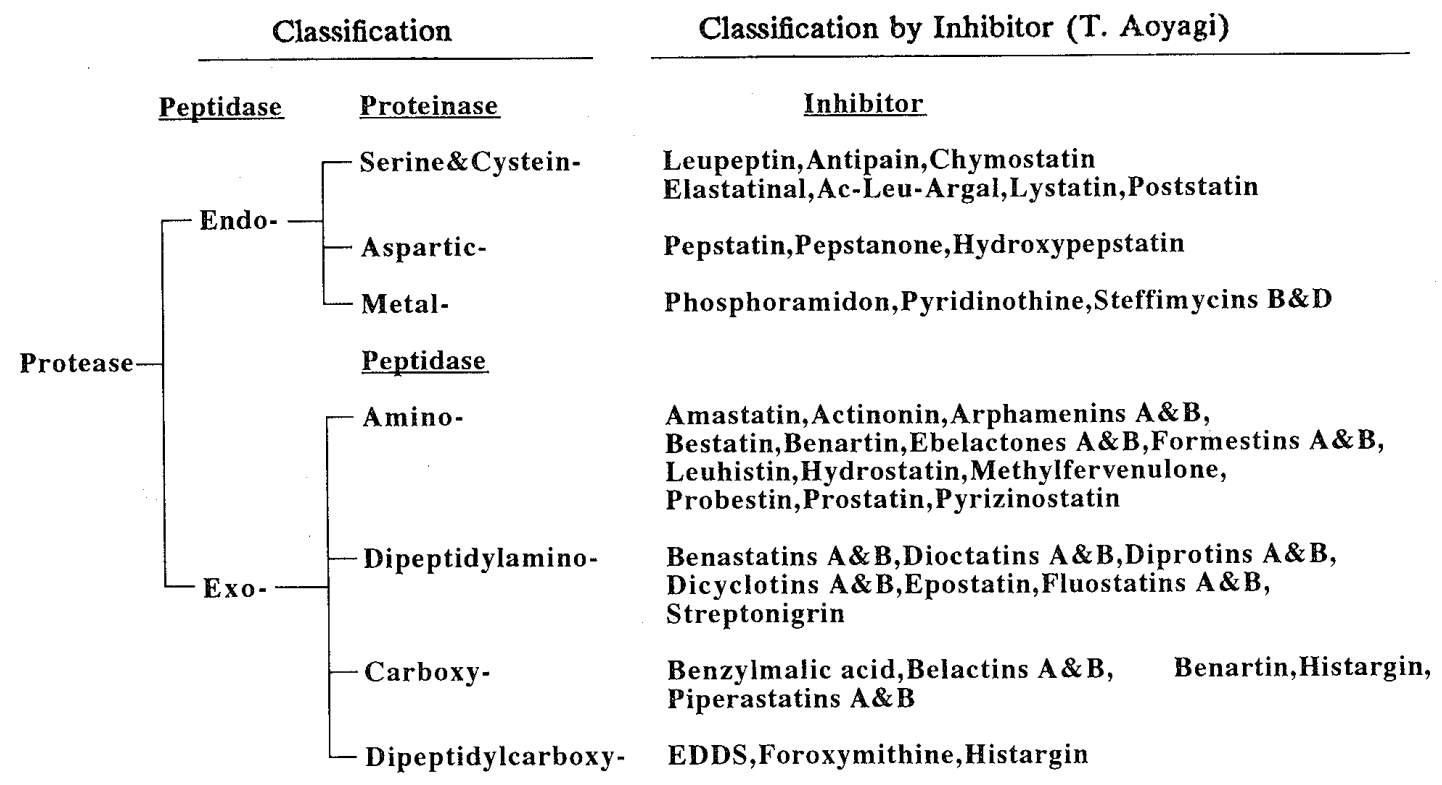

Fig. 1. Classification of Proteases by Inhibitors

ンザイムに対する阻害物質の発見は細胞膜と細胞機能との関連性に大きな示唆を与え, 免疫学 の分子レベルの研究に役立っている.

\section{II. 病態生理学からみた酵素阻害物質}

難病を含む多くの病気を解析し, 病因にもっとも深い関係を有する酵素を決め, この標的酵 素に対する阻害物質を探索し，治療に貢献することを目的とした研究である.

1. 病態解析 a) 筋ジストロフィ一症—Duchenne 型筋ジストロフィー症では筋繊維 の壊死,さらにそれに伴う貪食反応, 再生などが認められる. 筋繊維の変性, 壊死にプロテアー ゼが関与することが示唆され，1979 年から 12 年間に亘り厚生省新薬開発研究班として「低分 子酵素阻害物質による難病治療の開発研究」が施行された. 筋ジストロフィー症の病因解明並 びに Leupeptin, E64 誘導体及び Bestatinなどが治験楽として用いられ，大きな成果が得られ た. ${ }^{11-16)}$

b) 自己免疫疾患症一一根本的治療法のない難病である全身性エリテマトーデス, 進行性全 身硬化症, 慢性関節リウマチなどを含む膠原病また脱髄性神経疾患症, 重症筋無力症なよ゙を対 象之し，1986 年から5 年間に亘り厚生省新楽開発研究班として「自己免疫疾患の治療薬の開発 研究」が施行された。これらの疾患に対する治療薬として, 15-Deoxyspergualin, Bactobolamine, Poststatin などが用いられ，大きな期待が奇せられている。 ${ }^{17-23)}$

2. 病態生理からみた酵素阻害物質高血圧症, 高脂血症, 糖尿病, 老人性痴呆症, 自己免 疫疾患症, 筋ジストロフィー症などの患者血清, 病理解剖後の臓器並びに病態モデル動物の血 清並びに臓器などの酵素活性の变動を経時的に調べ，標的酵素に対する阻害効果を調べた。筋 ジストロフィー症並びに自己免疫疾患症に関しては既に述べた。東京都老人総合研究所の疾呆 プロジェクトで「アルッハイマー病とプロテアーゼ」に関する研究を施行した. 病理解剖後の 患者脳及び血清中の酵素活性の变動を調べた結果, 血液凝固系, 繊維素溶解系, キニン形成系 などに関与する酵素の異常を認めた。 ${ }^{24-33)}$

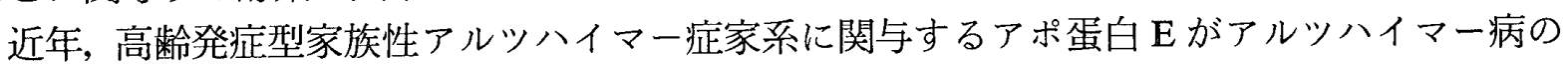
危険因子として注目されている.リポ蛋白中でのアポ蛋白 $\mathrm{E}$ の役割, また isoform と高脂血症, 
動脈硬化，アルツハイマー症などを中心とした痴呆を呈する疾患との関係を明らかにするた め, apo E 3/3 及び apo E 3/4, 4/4 などの患者血清中の酵素の動態を究明している.

従来, 報告されていない酵素が各疾患と樑い関係にあることを示唆し，これらの標的酵素に 対する阻害物質の探索により，治療への新しいアプローチを可能にした。

\section{III.プロテアーゼ阻害物質}

1960 年代に始まった低分子酵素阻害物質の研究は，酵素の反応機構，立体構造の解明，ア フィニティクロマトグラフィーの活性基，また活性物質精製時に起こる酵素分解を防ぎ，遺伝 子工学の領域に不可欠なあのとして, 医学, 薬学, 農学, 生化学, 生物学などの領域で汎用さ れている. さらに, 炎症, 免疫, 癌, ウイルス感染, 糖㽷病, 高血圧症, 高脂血症, 筋ジス卜 ロフィ一症, 自己免疫疾患症, 老人性痴呆症などを含む，様々な疾病の病因の解明と治療への アプローチを可能にした。まさに，“第3 世代の研究”とよばれるべきものである.

1.エンドペプチダーゼ阻害物質 血液凝固系, 繊維素溶解系, キニン形成系及び補体系 に関与する多くの酵素はエンドペプチダーゼに属する (Fig. 2).

セリン・システインプロテアーゼに属する酵素に対して Leupeptin, Antipain, Elastatinal, Chymostatin, Poststatin などを発見した。 また酸性プロテアーゼ阻害物質として Pepstatin 群を 見い出した。Pepstatin はレニンを阻害することから，高血圧症の治療薬としての関心が高ま りまた，HIV (human immunodeficiency virus) の酸性プロテアーゼを阻害することから， Pepstatin 構造中の statin[(3S,4S)-4-amino-3-hydroxy-6-methylheptanoic acid] を応用した多くの 化合物が合成され，エイズ撲滅へ熱い視線が注がれている。 また，メタロプロテアーゼに属す るコラゲナーゼ，サーモライシンなどを阻害する Actinonin, Steffimycin, Phosphoramidon など, さらに Phosphoramidon はエンドセリン変換酵素を阻害することで注目されている。Actinonin は IV 型コラゲナーゼに阻害活性を示す。上記阻害物質の構造並びに阻害機構は Fig. $3(1,2)$ 及

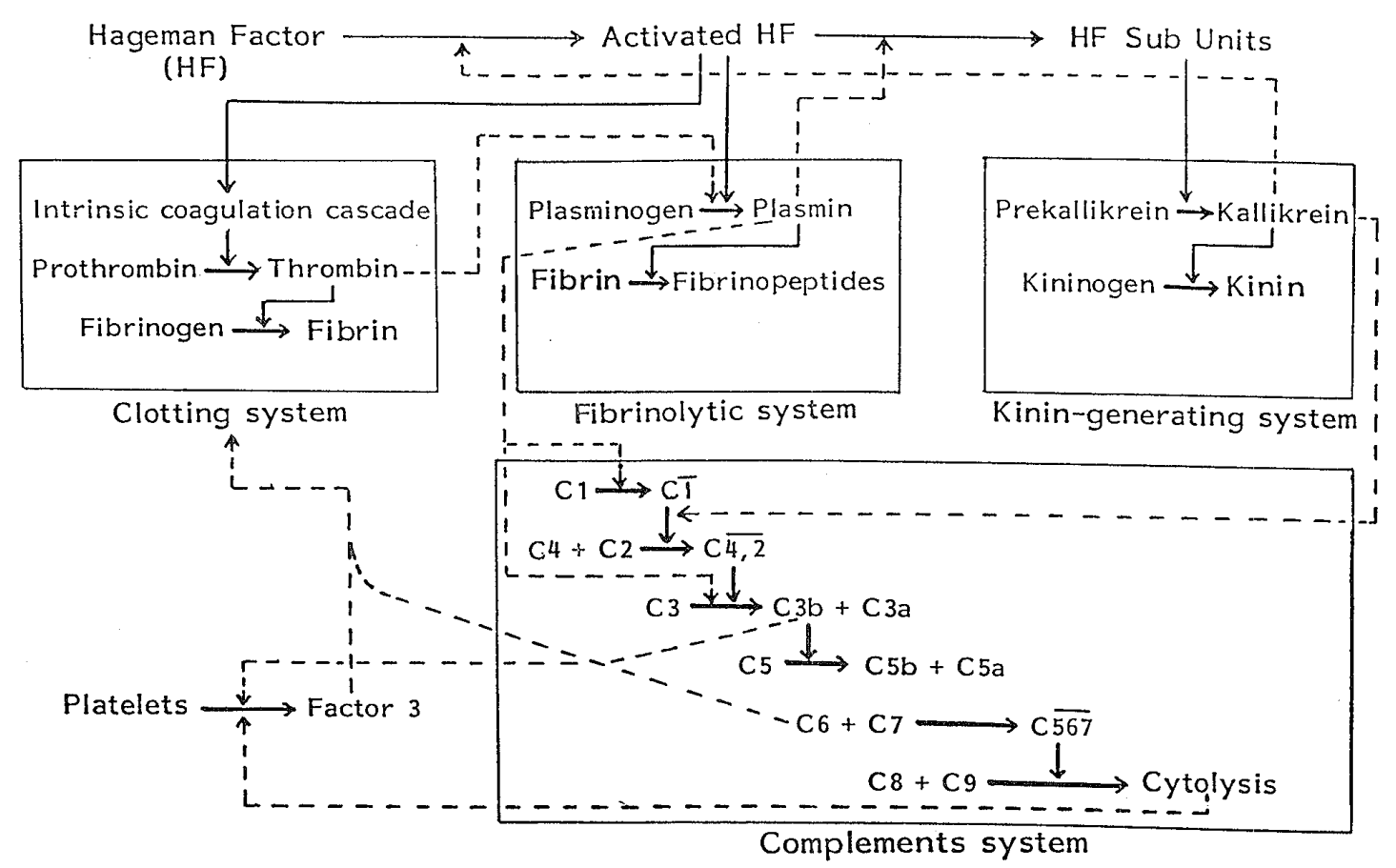

Fig. 2. Clotting System, Fibrinolytic System, Kinin-generating System and Complements System 


\section{Leupeptin}

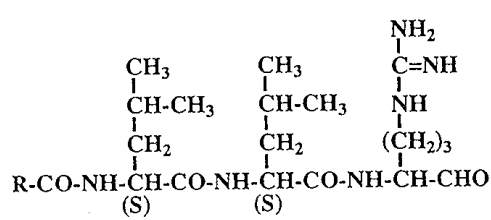

Chymostatin<smiles>CCCc1ccccc1</smiles>
HOOC-CH

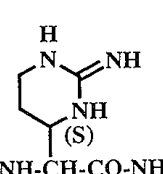

(S)<smiles>CC(C)CCc1ccccc1</smiles>

(S)

\section{Antipain}

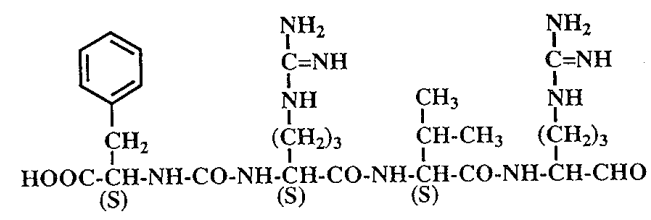

Elastatinal

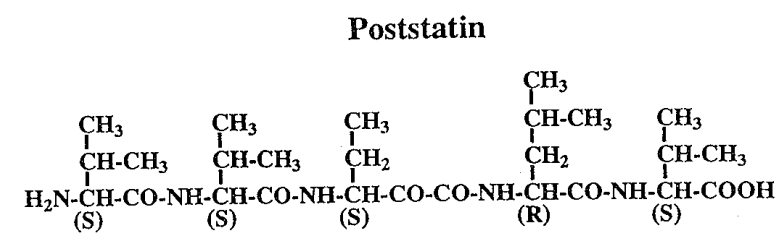

Fig. 3. Structure of Endopeptidase (Serine-, Cysteine-Proteinase) Inhibitors (1)

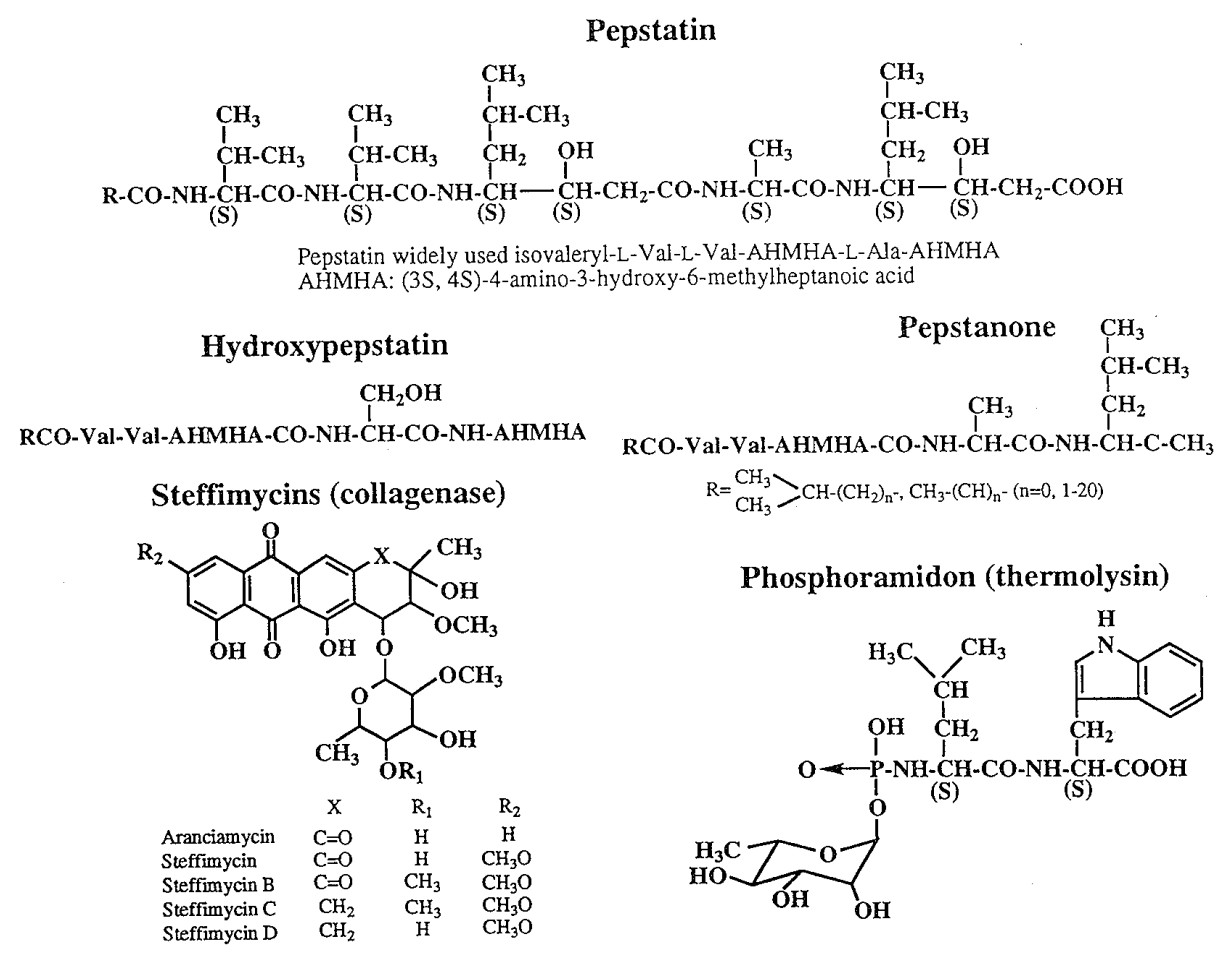

Fig. 3. Structure of Endopeptidase (Aspartic-, Metallo-Proteinase) Inhibitors (2)

び Table 1 に示す. ${ }^{1-10)}$

2. エキソペプチダーゼ阻害物質 細胞が外部環境に適応し，よりよい条件下で生存する ためには，細胞はその表面に様々な特異性のある作用を有する特殊な構造を，長い進化の過程 でつくり出してきたと考えられる．細胞膜の諸現象と細胞機能との関係を研究することは, 生 命現象を明らかにするための新しい分子生物学が指向する重要な研究分野である. 
Table 1. Kinetic Constants of Endopeptidase Inhibitors

\begin{tabular}{|c|c|c|c|c|c|}
\hline Inhbitor & Enzyme & Substrate & $\begin{array}{c}K_{\mathrm{m}} \\
\left(\times 10^{-4} \mathrm{M}\right)\end{array}$ & $\begin{array}{c}K_{\mathrm{i}} \\
\left(\times 10^{-7} \mathrm{M}\right)\end{array}$ & $\begin{array}{l}\text { Type of } \\
\text { inhibition }\end{array}$ \\
\hline \multirow[t]{2}{*}{ Leupeptin } & \multirow[t]{2}{*}{ Trypsin } & $\mathrm{TAME} \mathrm{E}^{c)}$ & 7.1 & 3.4 & Competitive \\
\hline & & $\mathrm{BAEE}^{d)}$ & 4.8 & 1.3 & Competitive \\
\hline \multirow[t]{2}{*}{ Elastatinal } & \multirow[t]{2}{*}{ Elastase } & $\mathrm{Ac}-(\mathrm{Ala})_{3} \cdot \mathrm{NA}^{e)}$ & 3.2 & 2.4 & Competitive \\
\hline & & $\mathrm{Ac}-(\mathrm{Ala})_{3} \cdot \mathrm{ME}$ & 4.3 & 2.1 & Competitive \\
\hline Poststatin & $\left.\mathrm{PEP}^{b}\right)$ & $\mathrm{Z} \cdot \mathrm{Gly} \cdot \operatorname{Pro} \cdot \mathrm{NA}^{f}$ & 4.0 & 0.56 & Competitive \\
\hline Pepstatin & Pepsin & $\begin{array}{c}\text { Phe-Gly-His-Phe }\left(\mathrm{NO}_{2}\right) \text { - } \\
\text { Phe-Ala-Phe } \cdot \mathrm{ME}\end{array}$ & 0.4 & 0.001 & Competitive \\
\hline \multirow[t]{3}{*}{ Phosphoramidon } & Thermolysin & Z-Gly-Leu $\cdot \mathrm{NH}_{2}{ }^{g)}$ & 20 & 0.28 & Competitive \\
\hline & B. subtilis & $\mathrm{Z}$-Gly-Leu $\cdot \mathrm{NH}_{2}$ & 33 & 65.0 & Competitive \\
\hline & B. griseus & $\mathrm{Z}$-Gly-Leu $\cdot \mathrm{NH}_{2}$ & 40 & 0.2 & Competitive \\
\hline \multirow[t]{3}{*}{ P-Leu-Trp ${ }^{a)}$} & Thermolysin & Z-Gly-Leu $\cdot \mathrm{NH}_{2}$ & 20 & 0.02 & Competitive \\
\hline & B. subtilis & Z-Gly-Leu $\cdot \mathrm{NH}_{2}$ & 33 & 3.0 & Competitive \\
\hline & B. griseus & Z-Gly-Leu $\cdot \mathrm{NH}_{2}$ & 40 & 0.01 & Competitive \\
\hline
\end{tabular}

a) L-Leucyl-L-tryptophan $N$-phosphate, $b$ ) prolyl endopeptidase, $c$ ) $a$ - $N$-(p-toluene sulfonyl)-L-arginine methyl ester $\mathrm{HCl}, d$ ) $a$ - $N$-benzoyl-L-arginine ethyl ester $\mathrm{HCl}, e$ ) acetyl-L-alanyl-L-alanyl-L-alanine $p$-nitroanilide, $f$ ) benzyloxycarbonyl-glycyl-L-proline $\beta$-naphthylamide, $g$ ) carbobenzoxyglycyl-L-leucineamide.

筆者らはインフルエンザウイルスの感染初期過程の研究から, 免疫担当細胞を含む各種の細 胞表面にアミノペプチダーゼ，ホスファターゼ，エステラーゼなどがエクトエンザイムとして 存在することを明らかにした。, 5, 34-39) エクトエンザイムに対する阻害物質は，細胞表面で酵 素一阻害物質複合体を形成し，細胞機能に影響を与える。この複合体の細胞機能に及ぼす影響を 解明することは，細胞表面と細胞機能との関連性を理解する鍵と考える。

アミノペプチダーゼ (AP) 阻害物質として Amastatin, Bestatin, Probestin, Leuhistin, Pyridinostatin, Formestin, Benarthin などを見い出した. Bestatin は，その構造に 3 個の不斉炭素を有す る．立体異性体と活性相関を調べた結果，2 位の配位が $S$ である (2S,3R)-3-amino-2-hydroxy-4phenylbutanoyl-(S)-leucine が活性体であることを明らかにした. Bestatin (Ubenimex) は免疫増 強作用に基づく抗悪性腫瘍活性が認められ，非リンパ性白血病の治療楽として臨床応用されて いる。 Bestatin は微生物起源の阻害物質として臨床応用された治療楽の第一号である. 上記阻 害物質の構造，阻害機構並びに免疫活性は Fig. 4 及び Table 2, 3 に示す. ${ }^{1-10)}$

ジペプチジルペプチダーゼ (DPP)-I, DPP-II, DPP-III 及び DPP-IV (CD26) に対する阻害物 質として，Dioctatin, Fluostatins 及び Diprotins などを見い出した．自己免疫疾患におけるDPP 及びその阻害物質の役割の解明は興味のある課題である。上記阻害物質の構造，阻害機構並び に免疫作用は, Fig. 5 及び Table 3, 4 に示す. ${ }^{7-10)}$

一方，カルボキシペプチダーゼ (CP) は metallo-CP と serine-CP に分けられている. Metallo$\mathrm{CP}$ に属する CP-A, CP-B, CP-H, CP-N 及びアンジオテンシン変換酵素 (ACE) などに対する阻 害物質として，Benzylmalic acid, Histargin, Foroxymithine などを，また serine-CPに属する CP-Y，血小板デアミナーゼなどに対する阻害物質として Piperastatins, ${ }^{40)}$ Belactins, ${ }^{41)}$ Ebelactones などを見い出した. 上記 2 群の酵素に対する阻害物質は極めて高い特異性を有し, 分子種 を明らかにするとともに生体内 CP の役割解明に貢献している.

ジペプチジルカルボキシペプチダーゼの阻害物質として，レニン・アンジオテンシン系の鍵 酵素である ACE の阻害物質として Histargin 及び Foroxymithin などを見い出したＡCE 阻害 
Amastatin (AP-A, AP-N, Leu-AP)

$\mathrm{CH}_{3}$

$\mathrm{CH}-\mathrm{CH}_{3} \quad \mathrm{CH}_{3} \quad \mathrm{CH}_{3}$

$\mathrm{CH}_{2} \mathrm{OH} \quad \mathrm{CH}-\mathrm{CH}_{3} \quad \stackrel{\mathrm{CH}-\mathrm{CH}_{3}}{\mathrm{CH}_{2}-\mathrm{COOH}}$ $\mathrm{H}_{2} \mathrm{~N}-\mathrm{CH}-\mathrm{CH}-\mathrm{CONH}-\mathrm{CH}-\mathrm{CONH}-\mathrm{CH}-\mathrm{CONH}-\mathrm{CH}-\mathrm{COOH}$

$$
\begin{array}{llll}
(\mathrm{R}) & \text { (S) } & \text { (S) } & \text { (S) }
\end{array}
$$

Arphamenines A \& B (AP-B)

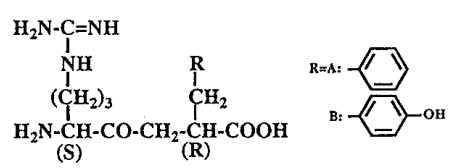

AHPA-Val-Phe (Leu-AP, AP-N)

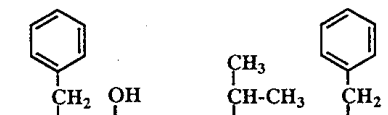

$\mathrm{NH}_{2}-\mathrm{CH}-\mathrm{CH}-\mathrm{CO}-\mathrm{NH}-\mathrm{CH}-\mathrm{CO}-\mathrm{NH}-\mathrm{CH}-\mathrm{COOH}$

(2S,3R)-3-amino-2-hydroxy-4-phenylbutanoyl-Val-Phe

Probestin (Leu-AP, AP-N)

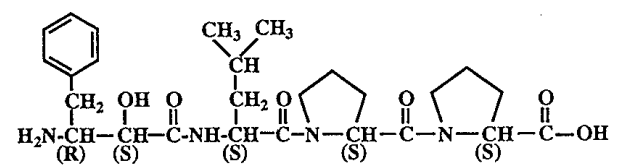

Pyrizinostatin

2-Methylfervenulone (PG-peptidase)<smiles>CC(=O)C[C@@]12NC(=O)N(C)N=C1N(C)C(=O)N(C)C2=O</smiles><smiles>CN1C(=O)c2nc(=O)n(C)c(=O)n2C1=O</smiles>

Formestins A \& B (f-Met-AP)

$\mathrm{CH}_{2} \mathrm{OH}$

(S) $\mathrm{C} \mathrm{HOH}$

$\stackrel{1}{\mathrm{C}=}$

$\mathrm{CH}_{3} \quad \mathrm{COOH}$ $\mathrm{C}=0$
1
$\mathrm{NH}$

Bestatin (AP-B, AP-N, Leu-AP)

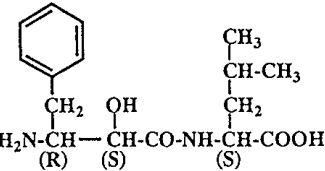

p-Hydroxybestatin (AP-B, Leu-AP)

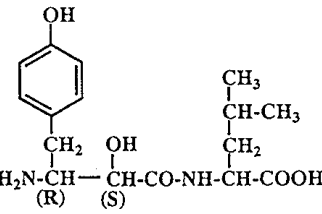

Actinonin (Leu-AP, AP-N)

$$
\begin{array}{ll}
\mathrm{CH}_{3} & \mathrm{CH}_{3} \\
\hline
\end{array}
$$

$\mathrm{CH}-\mathrm{CH}_{3} \quad\left(\mathrm{CH}_{2}\right)_{4}$

(S) $\mathrm{N}-\mathrm{CO}-\underset{\text { (S) }}{\mathrm{CH}}-\mathrm{NH}-\mathrm{CO}-\mathrm{CH}-\mathrm{CH}_{2}-\mathrm{CO}-\mathrm{NH}-\mathrm{OH}$

$\mathrm{CH}_{2} \mathrm{OH}$

Leuhistin (Leu-AP, AP-N)

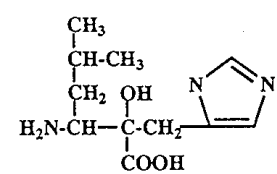

DHBS (Leu-AP)

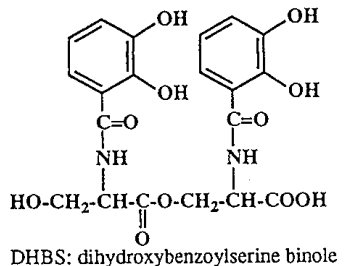

DHBS: dihydroxybenzoylserine binole

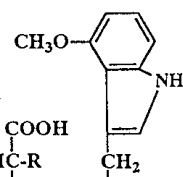

$\mathrm{CH}_{3} \mathrm{CH}_{2}\left(\mathrm{CH}_{2} \mathrm{CH}_{3} \mathrm{CONHCHCH}\right.$

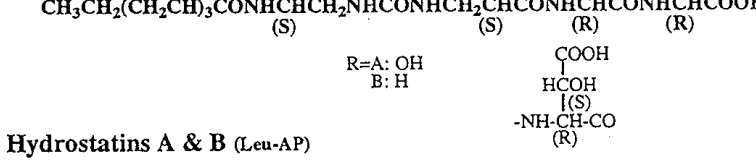

$\mathrm{CH}_{3}$

$\mathrm{CH}-\mathrm{CH}_{3} \quad \mathrm{CH}_{3}$

$\left.\underset{(\mathrm{C}}{\mathrm{C}} \mathrm{H}_{2}\right)_{\mathrm{n}} \mathrm{OH} \quad \stackrel{\mathrm{CH}}{\mathrm{O}}-\mathrm{CH}_{3}$ $\mathrm{H}_{2} \mathrm{~N}-\mathrm{CH}$ - $\mathrm{CH}-\mathrm{CO}-\mathrm{NH}-\mathrm{CH}-\mathrm{COOH}$ A: $n=2, B: n=1$

Ebelactones A \& B (f:Met-AP, lipase, CP.Y)

(S) (S) $\mathrm{CH}_{3}^{\mathrm{CH}_{3}} \quad \mathrm{CH}_{3} \quad \mathrm{CH}_{3} \stackrel{\mathrm{CH}_{3}}{\mathrm{CH}_{1}} \mathrm{CH}_{3}$

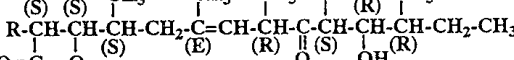
$\mathrm{O}=\stackrel{1}{\mathrm{C}}-\mathrm{O}^{\mathrm{O}}(\mathrm{S})$

$\mathrm{R}=\mathrm{A}:-\mathrm{CH}_{3}, \mathrm{~B}:-\mathrm{C}_{2} \mathrm{H}_{5}$

Benarthin (PG-peptidase)

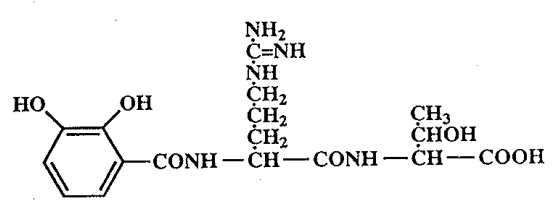

Pyridinothine

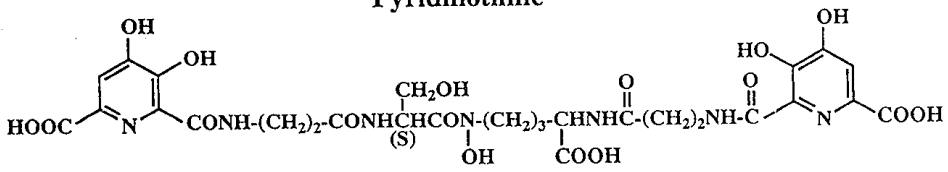

Fig. 4. Structure of Aminopeptidase Inhibitors 
Table 2. Kinetic Constants of Aminopeptidase Inhibitors

\begin{tabular}{|c|c|c|c|c|c|}
\hline Inhibitor & Enzyme & Substrate & $\begin{array}{c}K_{\mathrm{m}} \\
\left(\times 10^{-4} \mathrm{M}\right)\end{array}$ & $\begin{array}{c}K_{\mathrm{i}} \\
\left(\times 10^{-7} \mathrm{M}\right)\end{array}$ & $\begin{array}{l}\text { Type of } \\
\text { inhibiton }\end{array}$ \\
\hline Amastatin & AP-A & $\mathrm{Glu} \cdot \mathrm{NA}^{c)}$ & 8.0 & 2.5 & Competitive \\
\hline Amastatin & Leu-AP & $\mathrm{Leu} \cdot \mathrm{NA}$ & 37.0 & 16.0 & Competitive \\
\hline Bestatin & AP-B & $\mathrm{Arg} \cdot \mathrm{NA}$ & 1.0 & 0.6 & Competitive \\
\hline Bestatin & Leu-AP & $\mathrm{Leu} \cdot \mathrm{NA}$ & 5.8 & 0.2 & Competitive \\
\hline Arphamenine A & AP-B & $\mathrm{Arg} \cdot \mathrm{NA}$ & 1.0 & 0.025 & Competitive \\
\hline Arphamenine $\mathbb{B}$ & AP-B & Arg $\cdot$ NA & 1.0 & 0.008 & Competitive \\
\hline Ile-Arg & AP-B & $\mathrm{Arg} \cdot \mathrm{NA}$ & 1.0 & 5.0 & Competitive \\
\hline Val-Arg & AP-B & $\mathrm{Arg} \cdot \mathrm{NA}$ & 1.0 & 21.0 & Competitive \\
\hline Actinonin & $\mathrm{AP}-\mathrm{N}(\mathrm{M})$ & $\mathrm{Leu} \cdot \mathrm{NA}$ & 0.8 & 1.7 & Competitive \\
\hline Probestin & $\mathrm{AP}-\mathrm{N}(\mathrm{M})$ & $\mathrm{Leu} \cdot \mathrm{NA}$ & 0.8 & 0.19 & Competitive \\
\hline Leuhistin & $\mathrm{AP}-\mathrm{N}(\mathrm{M})$ & Leu $\cdot$ NA & 0.8 & 2.3 & Competitive \\
\hline Hydrostatin A & Leu-AP & Leu $\cdot \mathbf{N A}$ & 13.0 & 4.0 & Competitive \\
\hline Hydrostatin B & Leu-AP & Leu $\cdot \mathbf{N A}$ & 13.0 & 20.0 & Competitive \\
\hline AHPA-Val-Phe ${ }^{a)}$ & AP-N & $\mathrm{Leu} \cdot \mathrm{NA}$ & 0.8 & 0.295 & Competitive \\
\hline Pyrizinostatin & PG-peptidase ${ }^{b)}$ & PyrGlu $\cdot$ NA & 0.33 & - & Non competitive \\
\hline Benarthin & PG-peptidase & PyrGlu $\cdot$ NA & 0.33 & 12.0 & Competitive \\
\hline Formestin A & fMet-AP & fMet $\cdot \mathbf{N A}$ & 2.0 & 0.39 & Competitive \\
\hline Formestin B & fMet-AP & fMet $\cdot$ NA & 2.0 & 1.23 & Competitive \\
\hline Ebelactone A & fMet-AP & fMet $\cdot$ NA & 2.0 & 1.73 & Non competitive \\
\hline Ebelactone B & fMet-AP & fMet $\cdot$ NA & 2.0 & 0.63 & Non competitive \\
\hline
\end{tabular}

a) (2S,3R)-3-amino-2-hydroxy-4-phenylbutanoyl-L-valyl-L-phenylalanine, $b$ ) pyroglutamyl peptidase, c) L-glutamic acid $\beta$-naphthylamide.

Table 3. Immunological Effect of Low-Molecular-Weight Inhibitors

\begin{tabular}{ll|ll}
\hline \multicolumn{1}{c|}{ Inhibitor } & Immunity & \multicolumn{1}{|c}{ Inhibitor } & Immunity \\
\hline Amastatin & Humoral & Diprotin A & Cellular \\
Bestatin & Cellular & Diprotin B & Cellular \\
Arphamenine A & Cellular & Benzylmalic acid & Cellular \\
Arphamenine B & Cellular & Histargin & Cellular \\
Formestin A & Cellular & Foroxymithine & Cellular \\
Formestin B & Cellular & EDDS & Cellular \\
Actinonin & Cellular & Forphenicine & Cellular \\
Probestin & Humoral & Esterastin & Cellular \\
Prostatin & Humoral & Ebelactone A & Cellular \\
Leuhistin & Cellular & Ebelactone B & Cellular \\
Benadrostin & Humoral & Plipastatin A & Cellular \\
Dioctatin A & Cellular & Plipastatin B & Cellular \\
Dioctatin B & Cellular & Cyclooctatin & Cellular \\
\hline
\end{tabular}

EDDS; (s,s)-N,N'-ethylenediaminedisuccinic acid 


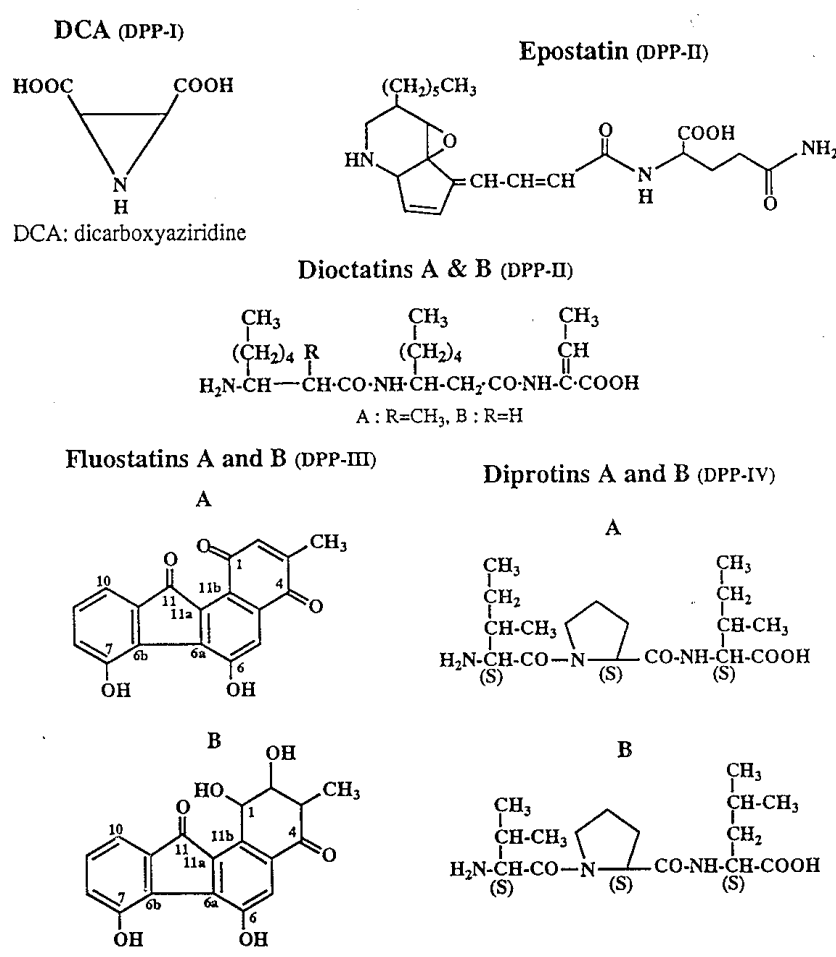

Fig. 5. Structure of Dipeptidylpeptidase Inhibitors

Table 4. Kinetic Constants of Dipeptidylpeptidase, Carboxypeptidase and Esterase Inhibitors

\begin{tabular}{|c|c|c|c|c|c|}
\hline Inhibitor & Enzyme & Substrate & $\begin{array}{c}K_{\mathrm{m}} \\
\left(\times 10^{-4} \mathrm{M}\right)\end{array}$ & $\begin{array}{c}K_{\mathrm{i}} \\
\left(\times 10^{-7} \mathrm{M}\right)\end{array}$ & $\begin{array}{l}\text { Type of } \\
\text { inhibition }\end{array}$ \\
\hline $\mathrm{DCA}^{a)}$ & DPP-I $\mathbf{I}^{b)}$ & $\mathrm{Gly}-\mathrm{Arg} \cdot \mathrm{NA}^{e)}$ & 8.0 & 42.0 & Competitive \\
\hline Epostatin & DPP-II & Lys-Ala $\cdot \mathrm{NA}$ & 14.3 & 14.4 & Competitive \\
\hline Fluostatin A & DPP-III & Arg-Arg $\cdot$ NA & 0.6 & 6.59 & Mixed type \\
\hline Fluostatin A & DPP-III & Leu-enkephalin & 0.1 & 142.0 & Competitive \\
\hline Diprotin A & DPP-IV & Gly-Pro·NA & 4.0 & 22.0 & Competitive \\
\hline Diprotin B & DPP-IV & Gly-Pro $\cdot$ NA & 4.0 & 76.0 & Competitive \\
\hline $\begin{array}{l}(S) \text { - } \alpha \text {-Benzylmalic } \\
\text { acid }\end{array}$ & $\mathrm{CP}-\mathrm{A}^{c)}$ & Hip-Phe ${ }^{f}$ & 10.0 & 6.7 & Competitive \\
\hline Histargin & CP-B & Hip-Lys & 62.0 & 320.0 & Competitive \\
\hline Foroxymithin & $\mathrm{ACE}^{d)}$ & His-His-Leu & 0.5 & - & Uncompetitive \\
\hline Piperastatin A & CP-Y & Bz-Gly-Phe & 20.0 & 0.43 & Competitive \\
\hline Forphenicine & Alkaline phosphatase & $\mathrm{NPP}^{g)}$ & 4.6 & - & Uncompetitive \\
\hline Esterastin & Esterase (pancreas) & $\mathrm{NPA}^{h)}$ & 4.0 & 0.002 & Competitive \\
\hline Ebelactone A & Esterase (liver) & NPA & 6.7 & 0.92 & Competitive \\
\hline Ebelactone B & Esterase (liver) & NPA & 6.7 & 0.005 & Competitive \\
\hline
\end{tabular}

a) 2,3-Dicarboxyaziridine, $b$ ) dipeptidylpeptidase $\mathrm{I}, c$ ) carboxypeptidase $\mathrm{A}, d$ ) angiotensin-converting enzyme, $e$ ) glycyl-L-arginine $\beta$-naphthylamide, $f$ ) hippuryl-L-phenylalanine, $g$ ) $p$-nitrophenyl phosphate, h) p-nitrophenyl acetate.

物質は醅素阻害物質研究の 1 つのエポックとして取り上げることができる、ACE の関与によ り生成されるブラジキニンとアンジオテンシンの形成と分解は Fig. 6 亿示す. CP-A と ACE は $\mathrm{Zn}^{2+}$ を含む酵素で CP-A は最あ詳しく研究された䣼素の1つである.

CP-A の活性部位から ACE の活性中心を推定し，ACE 阻害剤のドラッグデザインを試みた 


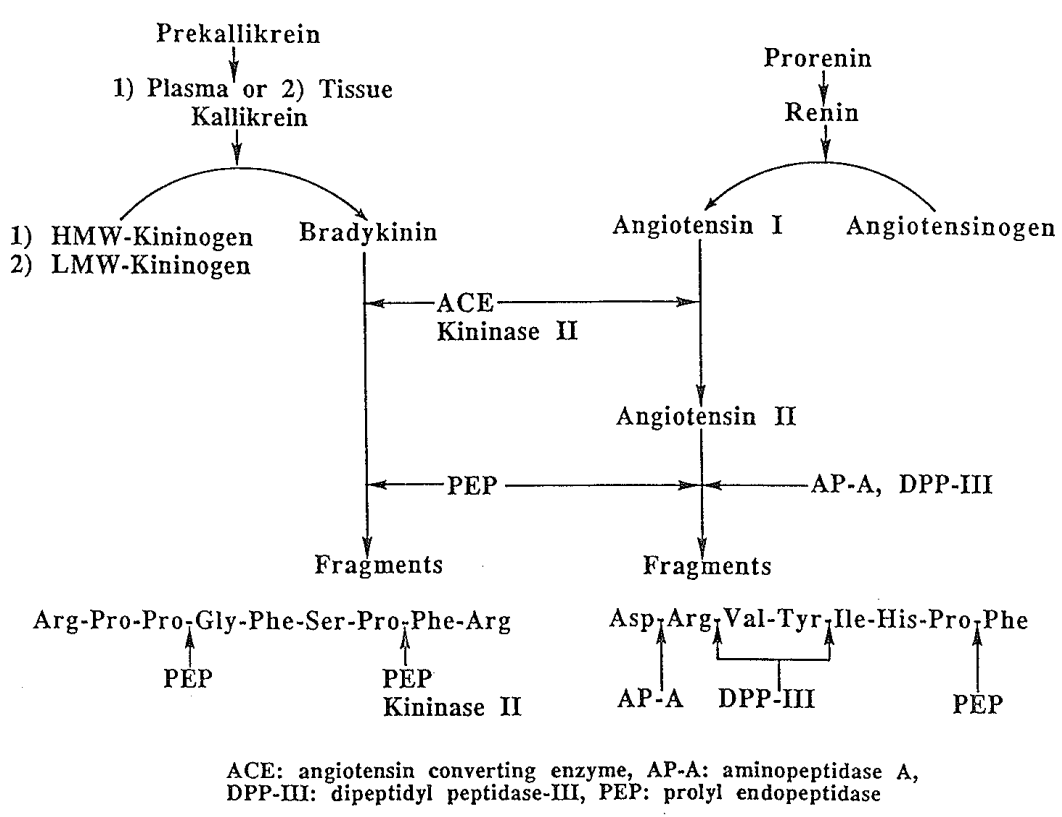

Fig. 6. Formation and Degradation of Bradykinin and Angiotensin II

(S)- $\alpha$-Benzylmalic acid (CP-A)<smiles>O=C(O)CC(O)(Cc1ccccc1)C(=O)O</smiles>

Histargin (CP-B, H, N, ACE)<smiles>CCc1cnc[nH]1</smiles>

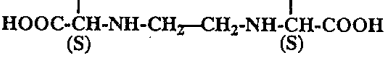

Arphamenines A \& B (CP-A, AP-B)

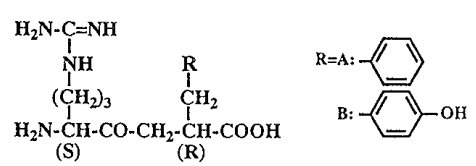

D, L,-2-mercaptomethyl-3-guanidinomethylthiopropanoic acid (MGPA; CP-B, H, N)<smiles>N#CNCSCC(CS)C(=O)OCC(C(=O)O)C(=O)O</smiles>

Fig. 7. Structure of Metallo-Carboxypeptidase Inhibitors

ことはまことに賢明であった．膨大な研究の結果，1日 1 回の経口投与で血圧をコントロール することが可能な薬剤が開発され，治療薬としての目的が達せられたと思われる。ドラッグデ ザインの典型的な成功例である。上記阻害物質の構造, 阻害活性並びに免疫活性は Fig. 7,8 及. び Table 3, 4, 5 に示す. ${ }^{7-10,24-28)}$

\section{IV. 糖鎖関連酵素阻害物質}

細胞表面に存在する糖蛋白質や糖脂質の糖鎖は細胞間の認識, 情報伝達や細胞の分化などに 重要な役割を果たし，細胞の相互認識，細胞表面抗原，ウイルス感染，癌転移，免疫などと深 い関係を有する．また，多くのエクトエンザイムが CD 抗原 (cluster of differentiation antigen) として分類され，エクトエンザイム及びその阻害物質の役割が細胞機能を理解する鍵として注 
Piperastatins A \& B (CP.Y, Pl-dA)

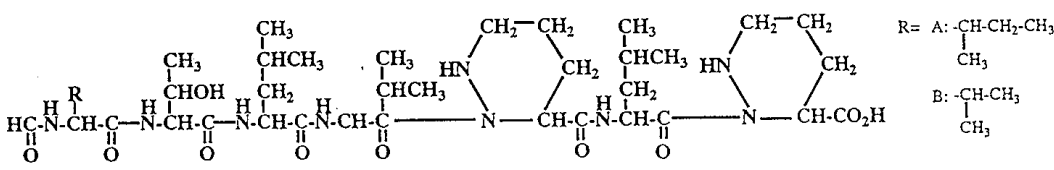

Belactins A \& B (CP-Y)

Poststatin (CP-Y, Pl-dA)
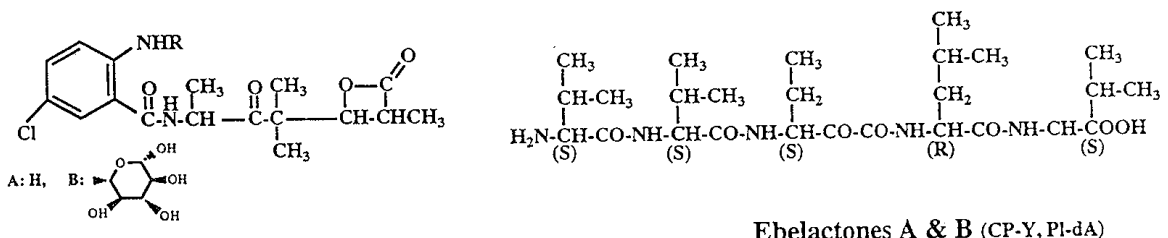

Esterastin (CP-Y, Pl-dA

Ebelactones A \& B (CP.Y,Pl-dA)

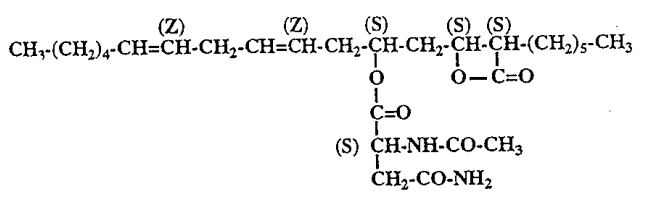

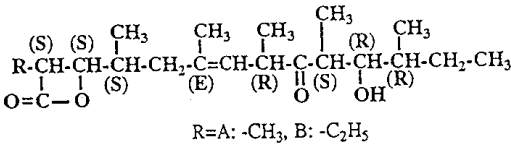

Fig. 8. Structure of Serine-Carboxypeptidase Inhibitors

Table 5. Inhibitory Activities of Various Inhibitors on Metallo- and Serine-Carboxypeptidases

\begin{tabular}{|c|c|c|c|c|c|c|c|}
\hline \multirow{3}{*}{ Inhibitor } & \multicolumn{7}{|c|}{$\mathrm{IC}_{50}(\mu \mathrm{g} / \mathrm{ml})$} \\
\hline & \multicolumn{3}{|c|}{ Metallo-Carboxypeptidase } & \multicolumn{3}{|c|}{ Serine-Carboxypeptidase } & \multirow{2}{*}{$\mathrm{ACE}$} \\
\hline & CP-A & CP-B & $\mathrm{CP}-\mathrm{N}$ & $\mathrm{CP}-\mathrm{W}$ & $\mathrm{CP}-\mathrm{Y}$ & Deaminase & \\
\hline Benzylmalic acid & 0.4 & 10 & $>100$ & $>100$ & $>100$ & $>100$ & $>100$ \\
\hline Arphamenine A & 90 & $>100$ & $>100$ & $>100$ & $>100$ & $>100$ & $>100$ \\
\hline Arphamenine B & 5.2 & $>100$ & 75 & $>100$ & $>100$ & $>100$ & $>100$ \\
\hline Histargin & $>100$ & 17 & 6.0 & $>100$ & $>100$ & $>100$ & 1.6 \\
\hline Foroxymithin & $>100$ & $>100$ & $>100$ & $>100$ & $>100$ & $>100$ & 7.0 \\
\hline Piperastatin A & $>100$ & $>100$ & $>100$ & $>100$ & 0.052 & 8.4 & $>100$ \\
\hline Belactin A & $>100$ & $>100$ & $>100$ & 27.5 & 0.18 & $>100$ & $>100$ \\
\hline Belactin B & $>100$ & $>100$ & $>100$ & $>100$ & 0.65 & $>100$ & $>100$ \\
\hline Esterastin & $>100$ & $>100$ & $>100$ & 1.6 & 0.05 & 1.7 & $>100$ \\
\hline Ebelactone A & $>100$ & $>100$ & $>100$ & 3.8 & 0.05 & $>100$ & $>100$ \\
\hline Ebelactone B & $>100$ & $>100$ & $>100$ & 0.2 & 0.002 & 2.2 & $>100$ \\
\hline Poststatin & $>100$ & $>100$ & $>100$ & $>100$ & $>100$ & 2.9 & $>100$ \\
\hline Chymostatin & $>100$ & $>100$ & $>100$ & $>100$ & 5.0 & $>100$ & $>100$ \\
\hline
\end{tabular}

CP-A, bovine pancreas; CP-B, hog pancreas; CP-N, human serum; CP-W, wheat; CP-Y, human platelet; ACE, rabbit lung.

目されている．この視点から糖蛋白質あるいは糖脂質に作用するグリコシダーゼ，トランス フェラーゼ並びにそれらの阻害物質の役割を理解することは, 疾病の機序を明らかにするとと 屯に，治療へのアプローチを可能にすることが期待される.

糖鎖関連酵素，すなわち，シアリダーゼ，グリコシダーゼ，ガラクトシダーゼ，マンノシダー ゼ，N-Ac-グルコサミニダーゼなどを標的酵素として， Siastatins，Pyridindolol，Mannostatins， Nagstatins, ${ }^{42)}$ Pyrostatins ${ }^{5,10,43)}$ など, 多くの阻害物質を見い出した。 上記阻害物質の阻害機構か ら，グリコシダーゼの分子種が明らかになった。阻害物質の構造並びに阻害活性は Fig. 9, Table 6 に示す. ${ }^{7-10,34-39)}$ 


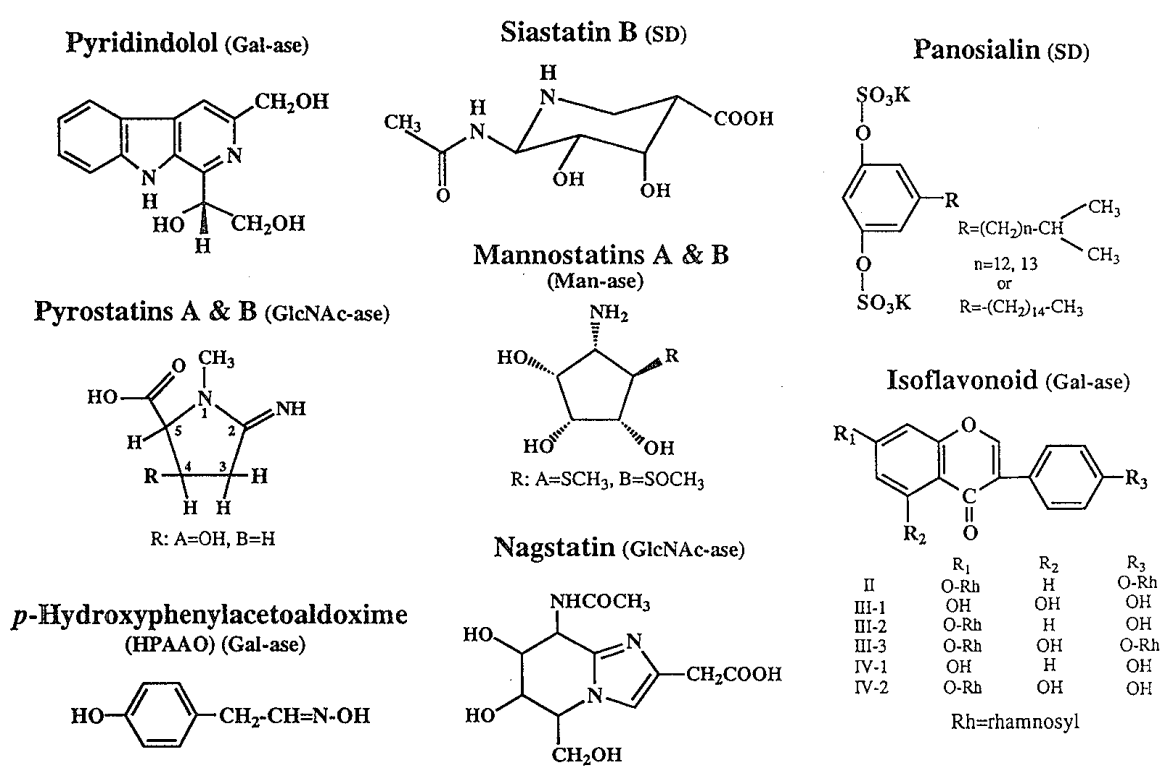

Fig. 9. Structure of Glycosidase Inhibitors

Table 6. Inhibitory Activities of Various Inhibitors on Glycosidases

\begin{tabular}{lcccc}
\hline \hline \multirow{2}{*}{ Inhibitor } & \multicolumn{3}{c}{$\mathrm{IC}_{50}(\mu \mathrm{g} / \mathrm{ml})$} \\
\cline { 2 - 5 } & Sialidase $^{a)}$ & $\begin{array}{c}\beta-\mathrm{D}- \\
\text { Galactosidase }^{b)}\end{array}$ & $\begin{array}{c}\alpha-\mathrm{D}- \\
\text { Mannosidase }^{c)}\end{array}$ & $\begin{array}{c}N \text {-Acetyl- } \beta \text {-D- } \\
\left.\text { Glucosaminidase }^{d}\right)\end{array}$ \\
\hline Siastatin B & 3.0 & $>100$ & $>100$ & $>100$ \\
Pyridindolol & $>100$ & 1.8 & $>100$ & $>100$ \\
Mannostatin A & $>100$ & $>100$ & 0.02 & $>100$ \\
Mannostatin B & $>100$ & $>100$ & 0.02 & $>100$ \\
Nagstatin & $>100$ & $>100$ & $>100$ & 0.002 \\
Pyrostatin A & $>100$ & $>100$ & $>100$ & 0.45 \\
Pyrostatin B & $>100$ & $>100$ & $>100$ & 0.82 \\
\hline
\end{tabular}

a) $C l$. perfringens, b) bovine liver, c) rat epididymis, d) hog kidney.

\section{V. 脂質関連酵素阻害物質}

コレステロール生合成の律速酵素である HMG-CoA (3-hydroxy-3-methylglutaryl coenzyme A) レダクターゼはメバロン酸合成に必須な酵素である。この HMG-Co A レダクターゼ阻害物 質として Compactin, Mevinolin などが報告されている。これらの阻害物質をリード化合物とし て膨大な化合物が合成され，この中のいくつかは高脂血症及び高コレステロールによる動脈硬 化症などの治療薬として繁用されている。また，スクワレンエポキシダーゼ阻害物質の探索及 び合成研究が活発に行われ，抗高脂血症薬の開発が盛んである．さらに，食欲や脂肪の代謝に 関与する肥満遺伝子が発見され，この遺伝子の変異が話題になっている。この遺伝子が作りだ すタンパクの「やせ薬」的効能が注目されている。

一方，リパーゼ，ホスホリパーゼ (PL)，リゾホスホリパーゼ (lyso-PL) などに対する阻害物 質として Esterastin, Ebelactones, Plipastatins, ${ }^{44)}$ Cyclooctatins ${ }^{45)}$ などを見い出した。 ${ }^{10)}$

Esterastin 及び Ebelactones A と B はエステラーゼ，リパーゼに強い阻害活性を示す。Ebelactone B はホルミルメチオニンアミノペプチダーゼにも阻害活性を示す。また, Plipastatin は 


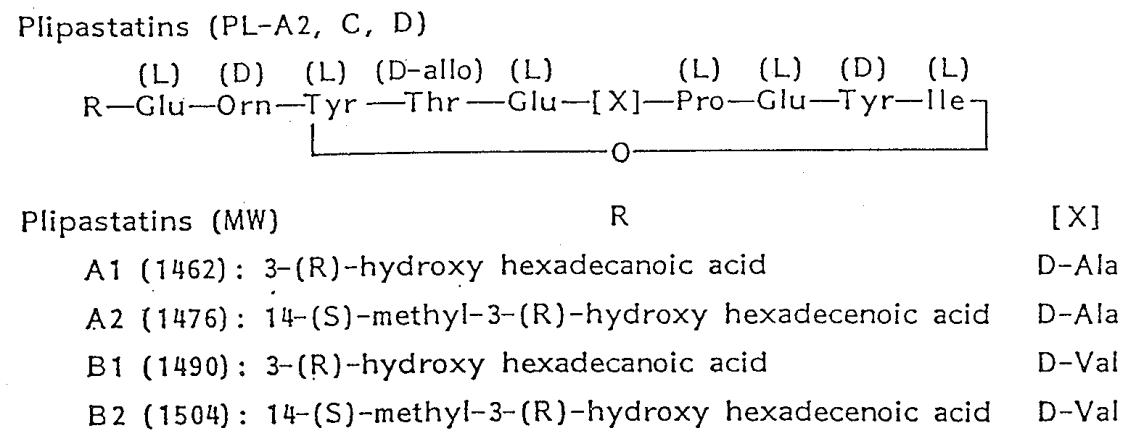

EDDS (292): (S, S)-N, $N^{\prime}-E$ thylenediaminedisuccinic Acid ( $P L-C, D$ and $A C E)$

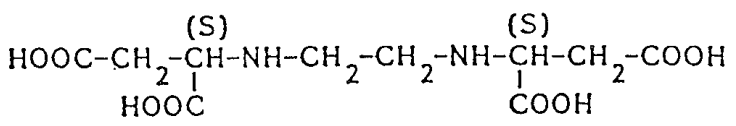

Fig. 10. Structure of Phospholipase Inhibitors<smiles>CCCCCCCCCCCCCC(=O)O</smiles><smiles>NC(C(=O)O)c1ccc(CO)c(O)c1</smiles>

Alphostatin

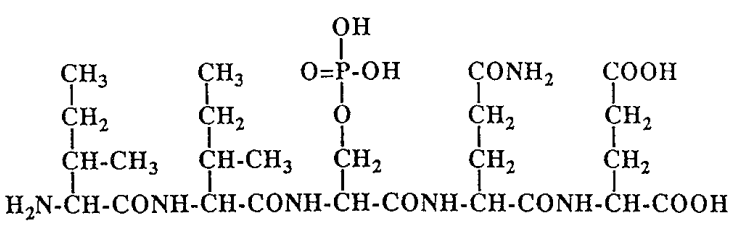

Fig. 11. Structure of Alkaline Phosphatase Inhibitors

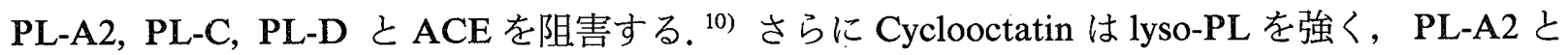
PL-C を弱く阻害する。一方, Ebelactone B は脂肪負荷 1 時間前に投与した時, 血清グリセライ ド及び血清総コレステロールの減少が認められ, 高脂血症及び肥満防止作用が示唆されてい る. ${ }^{46)}$ Plipastatins, EDDS の構造は Fig. 10 に示す. Esterastin, Ebelactones, Plipastatins, Cyclooctatins の免疫活性は Table 3 に示す.

\section{VI. その他の酵素阻害物質}

病因解明に対する生化学的研究の進歩に伴い, 酵素阻害物質の研究す日進月歩の感を呈し, 枚挙に暇なしの現状である.

1. ホスファターゼ・キナーゼ阻害物質 骨疾患, ベーチェット病, 胆道などの諸疾患に 関与するアルカリ性ホスファターゼを標的酵素として, Fig. 11 に示す Forphenicine, Alphostatin $^{47)}$ を見い出した. Forphenicine の免疫活性は Table 3 に示す.

一方, 癌, 高血圧症, 喘息, 糖尿病などの諸疾患時に変動する cAMP ホスホジェステラーゼ, また，癌遺伝子，抑制遺伝子に関し，チロシンキナーゼ，プロテインキナーゼを含む多くの研 究が報告され，さらに染色体末端部のテロメアと老化度などの問題に熱い視線が注がれてい る. 
2. グルタチオン S-トランスフェラーゼ阻害物質抗癌剤耐性腫瘍細胞の耐性機構に関与 し，またロイコトリエンC4 合成酵素として炎症，アレルギー反応に関与するグルタチオン Sトランスフェラーゼ (GST) に対する阻害物質を探索し，Fig. 12 に示す化合物を見出した。基<smiles>CCCCCc1cc2ccc3c(O)c4c(cc3c2c(O)c1P)C(C)(C)c1cc(O)cc(O)c1C4=O</smiles>

Benastatin A R=COOH Benastatin C R=H<smiles>CCCCCc1cc2c(c(O)c1P)-c1cc3c(c(O)c1C(O)C2)C(=O)c1c(O)cc(O)cc1C3=O</smiles>

Bequinostatin A $\mathrm{R}=\mathrm{COOH}$ Bequinostatin B R=H<smiles>[2H]c1c(CCCCC)cc2c(c1O)-c1cc3c(c(O)c1CC2)C(=O)c1c(O)cc(O)cc1C3(C)C</smiles>

Benastatin $\mathrm{B} \quad \mathrm{R}=\mathrm{COOH}$ Benastatin D R=H<smiles>[2H]c1c(CCCCC)cc2ccc3c(O)c4c(cc3c2c1O)C(=O)c1cc(O)cc(O)c1C4=O</smiles>

Bequinostatin $\mathrm{C}$ R=COOH Bequinostatin D $\mathbf{R}=\mathbf{H}$

Fig. 12. Structure of Glutatione Transferase Inhibitors

Table 7. Inhibitory Activities of Various Inhibitors on Glutatione Transferase Inhibitors

\begin{tabular}{|c|c|c|c|c|c|c|c|c|}
\hline \multirow{3}{*}{ Enzymes } & \multirow{3}{*}{ Substrates } & \multicolumn{7}{|c|}{$\mathrm{IC}_{50}(\mu \mathrm{g} / \mathrm{ml})$} \\
\hline & & \multicolumn{4}{|c|}{ Benastatins } & \multicolumn{2}{|c|}{ Bequinostatins } & \multirow{2}{*}{$\begin{array}{c}\text { Ethacrynio } \\
\text { acid }\end{array}$} \\
\hline & & A & B & $\mathrm{C}$ & $\mathrm{D}$ & A & B & \\
\hline Partially purified $\mathrm{GST}^{a)}$ & $\mathrm{DCNB}^{b)}$ & 2.50 & 0.92 & $>100$ & $>100$ & 1.40 & $>100$ & 0.95 \\
\hline Partially purified GST & $\mathrm{CDNB}^{c)}$ & 2.20 & 0.50 & 24.00 & 65.00 & 4.60 & 15.00 & 1.15 \\
\hline $\mathrm{GST} \pi$ & CDNB & 1.25 & 1.10 & 0.16 & 0.70 & 0.60 & 100 & 0.35 \\
\hline
\end{tabular}

a) Partially purified from rat liver, $b$ ) 3,4-dichloronitrobenzene, $c$ ) 1-chloro-2,4-dinitrobenzene.

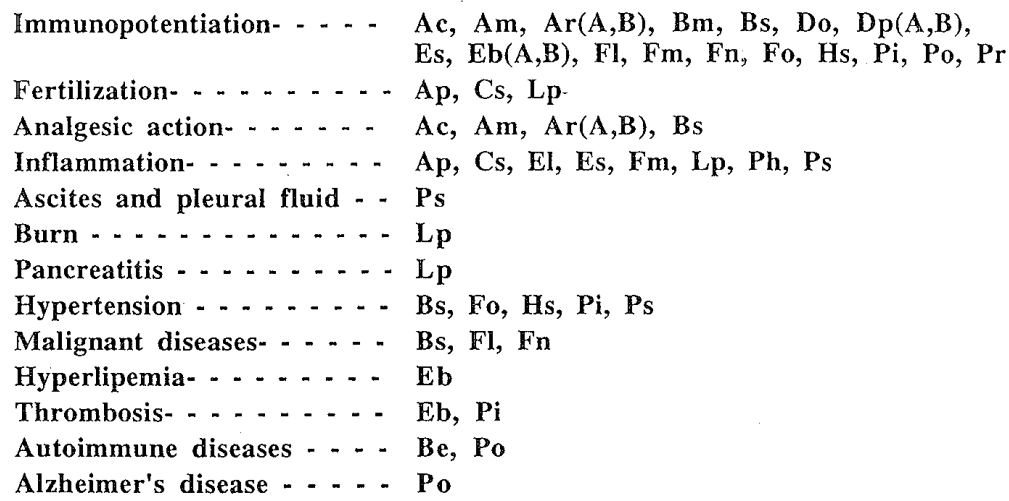

Am: amastatin, Ac: actinonin, Ap: antipain, Ar: arphamenine, Be: benastatin,

Bm: benzylmalic acid, Bs: bestatin, $\mathrm{Cs}$ : chymostatin, Do: dioctatin, Dp: diprotin,

Eb: ebelactone, El: elastatinal, Es: esterastin, Fl: forphenicinol, Fn: forphenicine, Fm: formestin, Fo: foroxymithine, Lp: leupeptin, Hs: histargin, Ph: phosphoramidon, Pi: piperastatin, Po: poststatin, Pr: probestin, Ps: pepstatin

Fig. 13. Biological and Therapeutic Effects of Enzyme Inhibitors 
本骨格が benzo $[\alpha]$ naphthacene である化合物を Benastatin, ${ }^{48)}$ benzo $[\alpha]$ naphthacenequinone であ る化合物を Bequinostatin ${ }^{49)}$ と命名した。 また GST の新規阻害物質として Cysfluoretin ${ }^{50)}$ を見い 出した。 上記阻害物質の各種 GST に対する阻害活性から GST の分子種が明らかになった。阻 害物質の構造並びに阻害活性は Fig. 12 と Table 7 に示す.

3. その他 ピログルタミルペプチダーゼ阻害物質として Pyridinostatin ${ }^{51)}$ 及び Benarthin $^{52)}$ を見い出した。また，poly(ADP-ribose) 合成酵素阻害物質として Benadrostin ${ }^{53)}$ 及び 2methyl-4[3H]quinazolinone ${ }^{54)}$ などを発見した。

上述の阻害物質は現在広範囲の基礎研究が行われているが，それぞれの阻害物質の薬理活性 についてはその要約を Fig. 13 に示す.

\section{おわりに}

微生物代謝産物から得られた低分子酵素阻害物質は酵素の反応機構の解析に，またアフィニ ティクロマトグラフィーの活性基として，あるいは複雑な生体反応に関与する酵素を識別する とともに病因を明らかにし, 医学, 薬学, 生化学, 生物学, 遺伝子工学などの広範囲の領域で 汎用されている。ささらに治療薬になりうることから多くの研究者の注目を集め, 合成研究者之 の協同で膨大な研究が進行中である.

日本で生まれ，そして育った酵素阻害物質の研究は多くの研究者の関心をよび，この分野の 急速な発展を導き, 生命科学の進歩に貢献しつつあることは望外の喜びである.

謝辞終始慈愛に満ちた御指導, 御鞭撻をいただいた恩師微生物化学研究所所長 故梅沢 浜夫先生並びに東京大学名誉教授 水野伝一先生に心より感謝申し上げます.

本研究を施行するにあたり, 御懇篤な御鞭撻を戴いた微生物化学研究所所長 竹内富雄先 生, また, 御指導, 御協力を戴いた研究所の諸先生方に深く御礼申し上げます.

さらに，本研究の続行にあたり温かい御厚情と御鞭撻を賜わった昭和薬科大学の諸先生に厚 く御礼申し上げます。

\section{引用 文 献}

1) Umezawa H., "Enzyme Inhibitors of Microbial Origin," University of Tokyo Press, Tokyo, 1972, pp. $1-114$.

2) Aoyagi T., Umezawa H., "Proteases and Biological Control," ed. by Reich E., Riffkin D. B., Show E., Cold Spring Harbor Laboratory, New York, 1975, pp. 429-454.

3) Aoyagi T., "Bioactive Peptides Produced by Microorganisms," ed. by Umezawa H., Takita T., Shiba T., Kodansha, Tokyo \& Wiley, New York, 1978, pp. 129-151.

4) Umezawa H., "Methods in Enzymology," vol. 45, ed. by Lorand L., Academic Press, New York, 1978, Chap. 55.

5）青柳高明，“酵素阻害物質，”共立全書 224，共立出版，東京，1978，pp. 1-189.

6）青柳高明, 代謝 (癌 '81)， 18, 879-889 (1981).

7) Aoyagi T., Ichikawa T., Maeda K., Mitscher L. A., "Japan, Antibiotics Research, Horizons on Antibiotic Research,” ed. by Davis B. D., Association, Tokyo, 1987, pp. 149-165.

8) Aoyagi T., "Intracellular Proteolysis-Mechanisms and Regulations," ed. by Katsunuma N., Kominami E., Japan Scientific Societies Press, Tokyo, 1989, pp. 377-383.

9) Aoyagi T., "Biochemistry of Peptide Antibiotics," ed. by Kleinkauf H., Dohrem H., Walter 
de Gruyter, Berlin, New York, 1990, pp. 311-363.

10) 青柳高明，蛋白質・核酸・酵素，38，1891 (1993).

11) Aoyagi T., Wada T., Kojima F., Nagai M., Umezawa H., J. Clin. Invest., 67, 51 (1981).

12) Aoyagi T., Wada T., Kojima F., Nagai M., Miyoshino S., Umezawa H., Clin. Chim. Acta, 129, 165 (1983).

13) Aoyagi T., Wada T., Yamamoto K., Kojima F., Nagai M., Umezawa H., J. PharmacobioDyn., 7, 312 (1984).

14) Aoyagi $\mathbb{T}$., Wada T., Ohuchi S., Kojima F., Nagai M., Harada S., Umezawa H., J. Pharmacobio-Dyn., 7, 681 (1984).

15) Aoyagi T., Wada T., Kojima F., Nagai M., Harada S., Umezawa H., Biotech. Appl. Biochem., 9, 355 (1987).

16）青柳高明, “筋ジストロフィー治療のチャレンジ一蛋白分解酵素阻害剂—” 厚生省新薬開 発研究編, 東京, 1991, pp. 51一62.

17) Aoyagi T., Wada T., Ishikawa Y., Kojima F., Nagai M., Osanai T., Nagai Y., Umezawa H., J. Pharmacobio-Dyn., 6, 963 (1983).

18) Aoyagi T., Wada T., Nagai M., Sakaguchi H., Osanai T., Nagai Y., Umezawa H., Experientia, 40, 1405 (1984).

19) Aoyagi T., Wada T., Kojima F., Nagai M., Okubo M., Masaki Y., Umezawa H., J. Appl. Biochem., 7, 273 (1985).

20) Aoyagi T., Wada T., Daskalov H. P., Kojima F., Nagai M., Harada S., Fujiwara M., Makino M., Umezawa H., Biochem. Int., 14, 435 (1987).

21) 青柳高明, Dementia, 5, 199 (1991).

22）青柳高明, 和田孝雄, 小林 悟, 広川勝ゆき, 積田 亨, 一瀬邦弘, 浜本 真, “老人性 痴呆に関する総合的研究，”東京都老人総合研究所編，1992, pp. 38-49.

23) Aoyagi T., Osanai T., Wada T., Kojima F., Nagai M., Harada S., Takeuchi T., Nagai Y., Chem. Pharm. Bull., 40, 1958 (1992).

24) Aoyagi T., Wada T., Kojima F., Harada S., Hachisu M., Murata S., Umezawa H., Biotech. Appl. Biochem., 8, 32 (1986).

25) Aoyagi T., Wada T., Kojima F., Nagai M., Harada S., Hachisu M., Murata S., Umezawa H., Chem. Pharm. Bull., 34, 4852 (1986).

26) Aoyagi T., Wada T., Kojima F., Nagai M., Harada S., Takeuchi T., Tsunoda K., Abe K., Yoshinaga K., Biotech. \& Appl. Biochem., 12, 258 (1990).

27) Aoyagi T., Wada T., Kojima F., Nagai M., Harada S., Takeuchi T., Tsunoda K., Abe K., Yoshinaga K., J. Clin. Biochem. Nutr., 9, 269 (1990).

28) Aoyagi T., Wada T., Nagai M., Kojima F., Harada S., Takeuchi T., J. Clin. Biochem. Nutr., 10, 35 (1991).

29) Aoyagi T., Wada T., Nagai M., Kojima F., Harada S., Takeuchi T., Takahashi H., Hirokawa K., Tsumita T., Experientia, 46, 95 (1990).

30) Aoyagi T., Wada T., Kojima F., Nagai M., Harada S., Takeuchi T., Takahashi H., Hirokawa K., Tsumita T., Chem. Pharm. Bull., 38, 1748 (1990).

31) Aoyagi T., Wada T., Kojima F., Nagai M., Harada S., Takahashi H., Hirokawa K., Chem. 
Pharm. Bull., 38, 1750 (1990).

32) Aoyagi T., Wada T., Kojima F., Nagai M., Harada S., Takeuchi T., Isse K., Ogura M., Hamamoto M., Tanaka K., Nagao T., Experientia, 48, 656 (1992).

33) Aoyagi T., Wada T., Kojima F., Nagai M., Harada S., Takeuchi T., Isse K., Ogura M., Hamamoto M., Tanaka K., Nagao T., J. Clin. Biochem. Nutr., 14, 133 (1993).

34) Kalckar H. M., Science, 150, 305 (1965).

35) Aoyagi T., Suzuki J., Nerome K., Nishizawa R., Takeuchi T., Umezawa H., Biochem. Biophys. Res. Comm., 57, 271 (1974).

36) Aoyagi T., Nerome K., Suzuki J., Takeuchi T., Umezawa H., Biochem. Biophys. Res. Comm., 60, 1178 (1974).

37) Aoyagi T., Komiyama T., Nerome K., Takeuchi T., Umezawa H., Experientia, 31, 896 (1975).

38) Aoyagi T., Suda H., Nagai M., Ogawa K., Suzuki J., Takeuchi T., Umezawa H., Biochim. Biophys. Acta, 452, 131 (1976).

39) Aoyagi T., Nagai M., Iwabuchi M., Liaw W. S., Andoh T., Umezawa H., Cancer Res., 38, 3505 (1978).

40) Murakami S., Harada S., Yamazaki T., Takahashi Y., Hamada M., Takeuchi T., Aoyagi T., J. Enz. Inhibition, 10, 93 (1996).

41) Murakami S., Harada S., Kojima F., Kinoshita N., Takahashi Y., Hamada M., Takeuchi T., Aoyagi T., J. Enz. Inhibition, 9, 263 (1995).

42) Aoyagi T., Suda H., Uotani K., Kojima F., Aoyama T., Horiguchi K., Hamada M., Takeuchi T., J. Antibiot., 45, 1404 (1992).

43) Aoyama T., Kojima F., Imada C., Muraoka Y., Naganawa H., Okami Y., Takeuchi T., Aoyagi T., J. Enz. Inhibition, 8, 223 (1995).

44) Umezawa H., Aoyagi T., Nishikiori T., Okuyama A., Yamagishi Y., Hamada M., Takeuchi T., J. Antibiot., 39, 737 (1986).

45) Aoyagi T., Aoyama T., Kojima F., Hattori S., Honma Y., Hamada M., Takeuchi T., J. Antibiot., 45, 1587 (1992).

46) Nonaka Y., Ohtaki H., Ohtsuka E., Kocha T., Fukuda T., Takeuchi T., Aoyagi T., J. Enz. Inhibition, 10, 57 (1995).

47) Aoyagi T., Morishima H., Kojiri K., Yamamoto T., Kojima F., Nagaoka K., Hamada M., Takeuchi T., Umezawa H., J. Antibiot., 42, 486 (1989).

48) Aoyagi T., Aoyama T., Kojima F., Matsuda N., Maruyama M., Hamada M., Takeuchi T., J. Antibiot., 45, 1385 (1992).

49) Aoyama T., Kojima F., Abe F., Muraoka Y., Naganawa H., Takeuchi T., Aoyagi T., J. Antibiot., 46, 914 (1993).

50) Aoyama T., Zhao W., Kojima F., Muraoka Y., Naganawa H., Takeuchi T., Aoyagi T., J. Antibiot., 46, 1471 (1993).

51) Aoyagi T., Hatsu M., Imada C., Naganawa H., Okami Y., Takeuchi T., J. Antibiot., 45, 1795 (1992).

52) Aoyagi T., Hatsu M., Kojima F., Hayashi C., Hamada M., Takeuchi T., J. Antibiot., 45, 1079 
(1992).

53) Aoyagi T., Yoshida S., Harada S., Okuyama A., Nakayama C., Yoshida T., Hamada M., Takeuchi T., Umezawa H., J. Antibiot,. 41, 1009 (1988).

54) Yoshida S., Aoyagi T., Harada S., Matsuda N., Ikeda T., Naganawa H., Hamada M., Takeuchi T., J. Antibiot., 44, 111 (1991). 